\title{
Sensitivity Analysis of Rock-Fill Dam Break Flood on Different Dam Break Durations
}

\author{
Changwen Li, Huabin Gao, Zhaoming Xu, Yan Huang \\ Changjiang Institute of Survey, Planning, Design and Research, Wuhan, China \\ Email: lichangwen@cjwsjy.com.cn
}

How to cite this paper: Li, C.W., Gao, H.B., Xu, Z.M. and Huang, Y. (2021) Sensitivity Analysis of Rock-Fill Dam Break Flood on Different Dam Break Durations. Open Journal of Safety Science and Technology, 11, 89-103.

https://doi.org/10.4236/ojsst.2021.113007

Received: June 29, 2021

Accepted: August 9, 2021

Published: August 12, 2021

Copyright $\odot 2021$ by author(s) and Scientific Research Publishing Inc. This work is licensed under the Creative Commons Attribution International License (CC BY 4.0).

http://creativecommons.org/licenses/by/4.0/

(c) (i) Open Access

\begin{abstract}
The dam break pattern of rock-fill dams is normally gradual failure. This kind of dam failure is caused by seepage piping or overtopping, in which dam crest overflow is more common. The dam breach expansion process shall depend comprehensively on the structure pattern, material property of dam, and damsite cross sectional topography. And the break duration has a significant impact on the magnitude of break flood and the counter-measures for excess-standard flood. Take the Karot Hydropower Project constructed on the Jhelum River in Pakistan as an example, the dam break mathematical model is set up to analyze the sensitivity of damsite discharge process, downstream highest flood water surface profile and flood peak appearance time to dam break duration. The results show that: with the increase of dam break duration, damsite peak discharge is decreased sharply, flood peak appearance time extends, on-way highest water levels below Karot dam are lowered significantly, and some settlement places below Karot dam can avoid being inundated until the break duration reaches a critical value. If encountering probable maximum flood, the dam break occurs when the reservoir water level reaches dam top EL, some measures can be taken to extend the break duration, so as to effectively reduce the loss of downstream flood. The research results will help to understand the relationship mechanism between rock-fill dam break flood and break duration and provide a scientific basis or some solutions for optimization design of dam and counter-measures of dam break flood.
\end{abstract}

\section{Keywords}

Rock-Fill Dam, Sensitivity Analysis, Dam Break Flood, Dam Break Duration

\section{Introduction}

Earth-rock or rock-fill dam is the most widely used dam type in reservoirs and dams. Taking China as an example, in 2018, it had nearly 100,000 reservoirs and 
dams, of which earth-rock dams accounted for more than 95\% [1] [2]. Compared with other dam types, earth-rock dams have suffered the most from natural disasters such as earthquakes and over-standard floods, and the damage degree is also more serious [3]. In recent years, with global climate change, the probability of dam failure caused by extreme weather has greatly increased [4]. From 1954 to 2017, a total of 3529 reservoir dams broke out in China, and in 2018, there were 12 more dam failures [5], of which dams below $30 \mathrm{~m}$ accounted for about $88 \%$ of the total dam failures [6]. These dam breaches have caused serious losses to the lives and property safety of the people downstream. Therefore, it is necessary to deeply study the collapse mechanism and break process of earth-rock dams.

Earth-rock dam failure mechanism and simulation of the failure process are the basis of dam-break disaster assessment and emergency treatment. After decades of research and exploration, domestic and foreign scholars have systematically revealed the failure mechanism of earth-rock dams under the action of different hazard factors, developed various mathematical models of dam breaks and obtained a series of innovative results, which provides theoretical support for improving prediction accuracy of dam break flood disaster [7]. Dam break patterns include sudden whole failure (or break) and gradual failure, the latter is further divided into gradual whole failure and gradual local failure, and the former (or also known as instantaneous break) normally occurs on gravity dam or arch dam, with very short break time; the gradual failure normally happens at the rock-fill dam, earth-rock dam and other types as well as earth-rock cofferdam [8] [9] [10]. The failure of rock-fill dam is caused by seepage piping or overtopping, in which dam crest overflow is more common, the type of dam breach can be approximated as rectangular or trapezoid, and the final size shall depend comprehensively on the material property of dam and damsite cross sectional topography [10] [11]. The Physical models should be used as supplement and calibration of Numerical models [12]. Some studies found that the vegetation and dam break shape play an important role in dam break flood wave [13]. Rock-fill dam break flood analysis is a very important basic work in early warning and emergency rescue work, and the accuracy of dam breach flood prediction can directly affect the formulation and implementation of emergency treatment plans; among them, the prediction of dam break durations is a prerequisite for risk assessment and emergency response [14]. According to relevant research, rock-fill dam break flood is sensitive for dam break duration, and the break duration has a significant impact on the magnitude of break flood and the counter-measures for excess-standard flood [15] [16].

Therefore, it is necessary to carry out in-depth research on the sensitivity of rock-fill dam break flood on different dam break durations, revealing the relationship between rock-fill dam break flood and break duration.

\section{Materials and Methods}

\subsection{Study Area}

Taking the Karot Hydropower Project constructed on the Jhelum River in Pa- 
kistan as an example, the sensitivity of damsite discharge process, downstream highest flood water surface profile and flood peak appearance time to dam break duration were researched.

Karot Hydropower Project is located in the Jhelum River in Pakistan, as shown in Figure 1. It's a Class II large (2) hydro project with damsite controlled catchment area of 26.7 thousand $\mathrm{km}^{2}$, mean annual discharge of $819 \mathrm{~m}^{3} / \mathrm{s}$, its full supply level (FSL) is $461 \mathrm{~m}$, corresponding reservoir capacity is 152 million $\mathrm{m}^{3}$. The water retaining structure of Karot Hydropower Engineering is an asphalt concrete core rockfill dam, with crest elevation level (EL) $469.5 \mathrm{~m}$, core bottom concrete pedestal foundation surface minimum EL $374.0 \mathrm{~m}$, maximum dam height of $95.5 \mathrm{~m}$ and dam crest length of $460 \mathrm{~m}$. Mangla Hydropower Station is at downstream of Karot Hydropower Station, which has a controlled drainage area of $33,333 \mathrm{~km}^{2}$, with mean annual runoff of 28.2 billion $\mathrm{m}^{3}$, the dam crest elevation is $388.32 \mathrm{~m}$, total reservoir capacity is 12.28 billion $\mathrm{m}^{3}$.

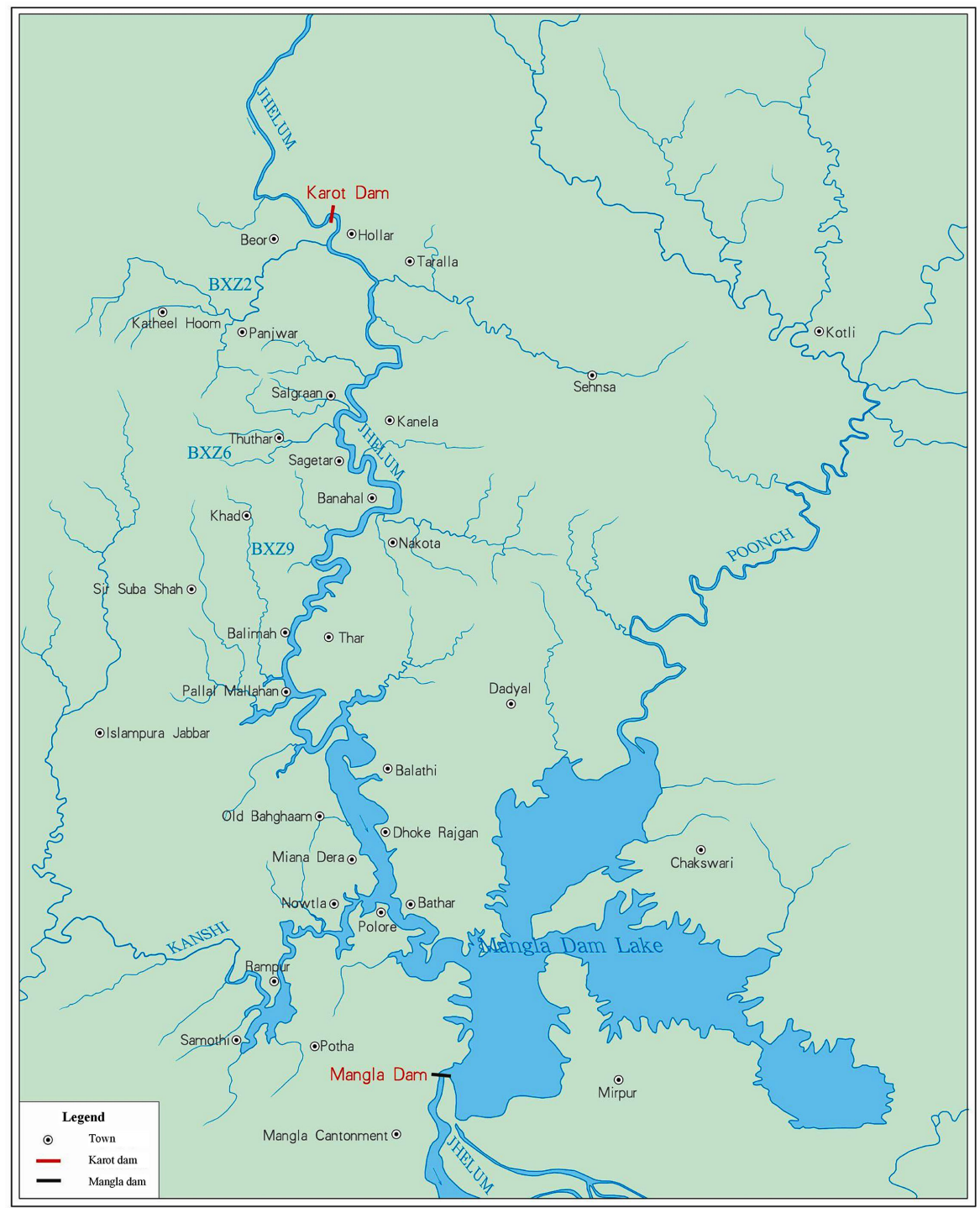

Figure 1. River network water system diagram of Jhelum River. 


\subsection{Dam Break Mathematical Model}

MIKE 11 calculation software is applied to build Karot Hydropower Station dam break hydrodynamic mathematical simulation model.

Dambreak structures are applied to simulate dam break in MIKE 11 [11] The 1D dam break model generalizes the dam breach into dam crest cross-flow hydraulic structure and dam breached hydraulic structure. This study involves gradual whole break led by dam crest overtopping.

Water flow process simulated by Karot Dam Break Model is as follows: before dam break, flow is discharged by flood releasing structures, reservoir level rises; after dam break, river channel permits flow, and its model is generalized as Figure 2. Dam break mathematical model is composed of river network module, section module, parameter module, structure module and boundary module.

1) River Network Module

River network module includes some information about river channel, such as river mileage, calculation range, flow direction, etc. Calculation range is the reach between Karot damsite to Mangla reservoir tail section. Simulated main tributaries include BXZ2, BXZ6, BXZ9 and Kanshi channels.

2) Section Module

Section module contains three parts: river channel section data, Karot Dam level-volume curve, and Mangla reservoir level-volume curve, the latter two parts are mainly used to simulate dam-retained channel storage volume.

Channel section: There are 75 measured sectional data within the modelling range provided by the Hydrology Bureau of Changjiang Water Resources Commission. The section locations are shown in Figure 3. The main stream within the modelling range has a length of $72.7 \mathrm{~km}$, containing 49 sections with average section gap of $1.5 \mathrm{~km}$; the tributaries within the modelling range have a length of $37.5 \mathrm{~km}$, totaling 26 sections, with average section gap of $1.7 \mathrm{~km}$.

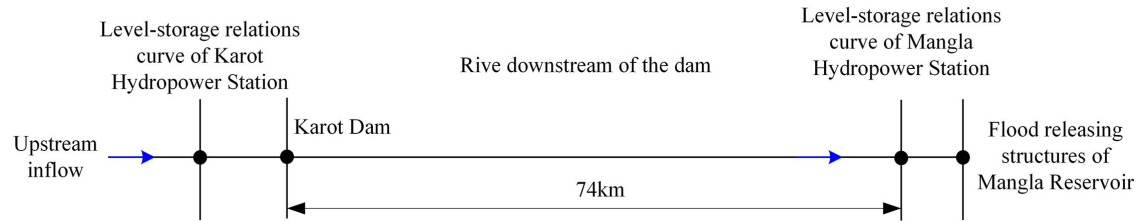

Figure 2. Generalization diagram of Karot Hydropower Station Dam Break Model.

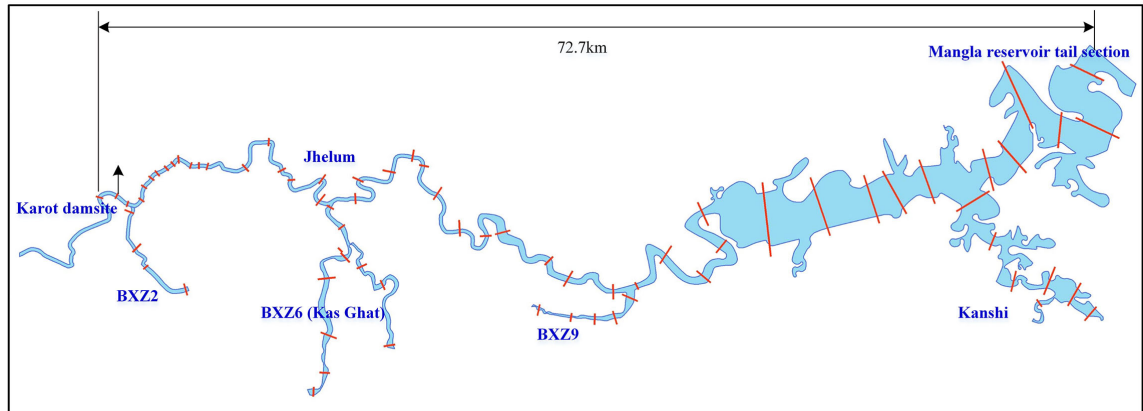

Figure 3. Schematic diagram of river channel section location. 
Level-volume curve of upstream reservoir of Karot Dam: The break flood of Karot dam consists of two parts, one part comes from upstream channel inflow and the other part is flood formed by sudden release of reservoir capacity retained by the dam, the latter is related to channel retained water volume above dam. The level-storage relation curve of Karot dam is simulated by adding storage area to the dam upstream section.

Downstream Mangla Reservoir level-volume curve: The reservoir capacity of Mangla Hydropower Station consists of 7 parts: upper Jhelum River, lower Jhelum River, Kanshi River, Poonch River, Mangla reservoir area, Khad reservoir area and Jari reservoir area. The water level-storage (area) of Mangla Hydropower Station is shown in Figure 4. The channel storage capacity is directly simulated for the former three parts based on measured section data, the storage capacity at different water levels is composed of channel segment storage capacity comprising adjacent channel section, and pyramid frustum cubature formula is applied for approximate calculation, as shown in Formula (1). Storage capacity of the latter four parts is obtained from Mangla Hydropower Station total storage capacity deducted from storage capacity of the former three parts at relevant water levels. Level-storage relation curve of Poonch River, Mangla reservoir area, Khad reservoir area and Jari reservoir area is simulated by adding storage area to dam upstream BX37 section.

$$
V=\frac{1}{3} \sum_{n}^{1}\left(S_{i}^{1}+\sqrt{S_{i}^{1} S_{i}^{2}}+S_{i}^{2}\right) L_{i}
$$

where, $V$ is the total storage capacity of upper Jhelum River and lower Jhelum River and Kanshi River at different water levels, in $\mathrm{m}^{3} ; S_{i}^{1}, S_{i}^{2}$ are starting and ending section area of the $i$ th section at different water levels, in $\mathrm{m}^{2} ; i$ is the number of channel segment joined by adjacent channel sections, there are 73 channel segments in total (including the number of segments in main tributary); $L_{i}$ is length between adjacent channel sections, in $\mathrm{m}$.

3) Structure Module

Structures in the dam break model include dam break, 6 surface overflow outlets (SOO) and 2 flood and sediment releasing outlets (FSO).

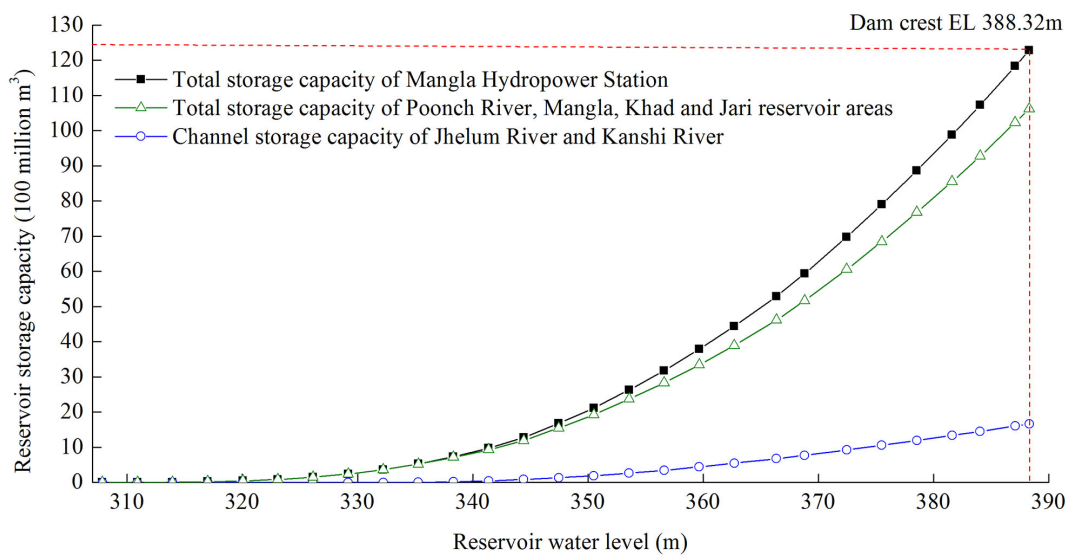

Figure 4. Level-storage relation curve of Mangla Hydropower Station. 
Dam break: Dam in structure module uses dam break structure for simulation, corresponding dam break method is: due to probable maximum flood (PMF), dam break occurs when the reservoir level of Karot Hydropower Station reaches dam crest EL $469.5 \mathrm{~m}$, and dam break duration is set in line with relevant experience and dam structure pattern.

Discharge structures: Discharge structures are considered for dam break flood simulation. Spillway in structure module adopts discharge capacity curve generalization, as shown in Figure 5, before dam break, spillway discharge flood; after dam break, flood overflow dam body while spillway discharge is not considered.

\subsection{Computational Conditions and Schemes}

After the occurrence of Karot dam break, its influence on the lower reach is related to the inflow from the upper reach, downstream boundary condition of water level discharge relation curve, dam-break mode, dam breach development process and other factors.

1) Upstream boundary condition

If encountering probable maximum flood, the dam break occurs when the reservoir water level reaches dam top EL $469.5 \mathrm{~m}$. The deluge in 1992 is the most serious flood at the Karot dam site since 1929. The flood process with a peak discharge of $35,650 \mathrm{~m}^{3} / \mathrm{s}$ is shown in Figure 6 . The catchment area between Azad Pattan damsite and Karot damsite is $215 \mathrm{~km}^{2}$, which only accounts for $0.8 \%$ of the catchment area of Karot damsite. Therefore, the PMF at the Azad Pattan damsite is served as the PMF at the Karot damsite. The peak discharge of PMF surpasses 10,000-year recurrence design flood $\left(32,300 \mathrm{~m}^{3} / \mathrm{s}\right)$ and check flood $\left(29,600 \mathrm{~m}^{3} / \mathrm{s}\right)$ at the Karot dam site.

2) Downstream boundary condition

The downstream boundary is situated at Mangla dam site. When Karot dam breaks, the downstream Mangla hydropower station release flood via discharge capacity curves of its normal and emergency spillways, and their discharge capacity relations are shown in Figure 7.

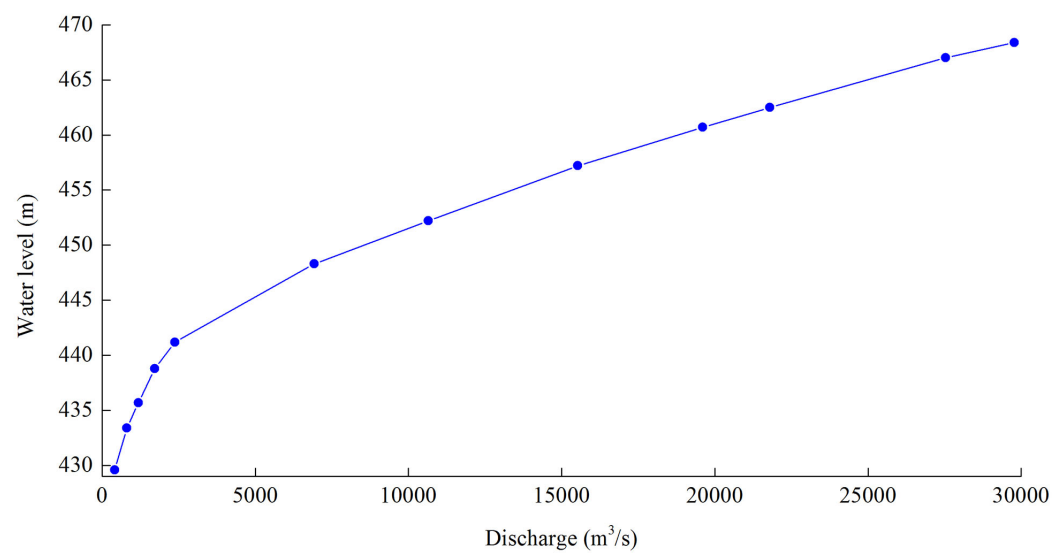

Figure 5. Discharge capacity curve of spillway of Karot Hydropower Station. 


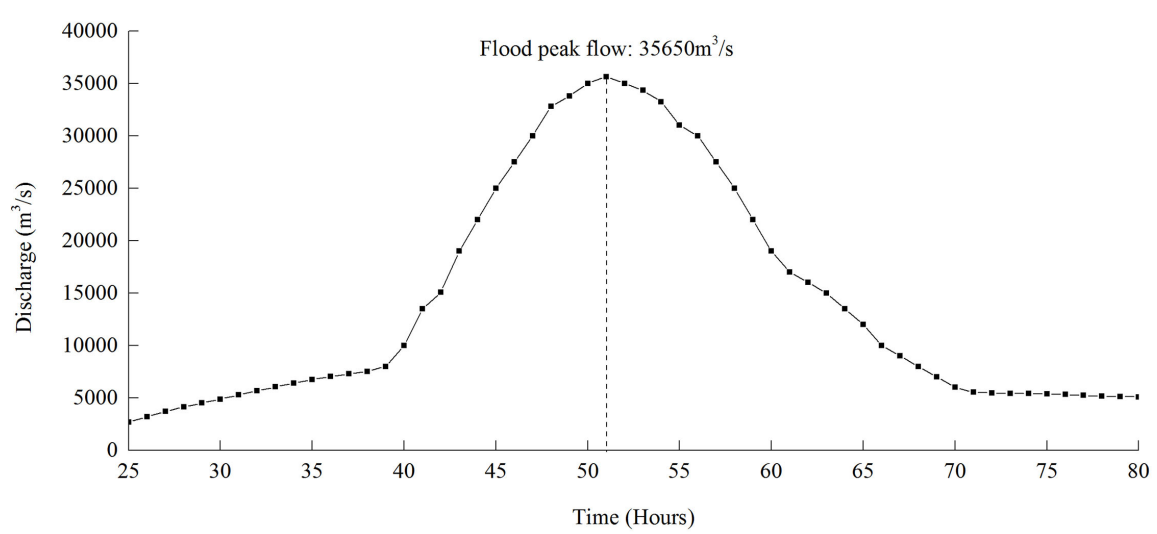

Figure 6. PMF at the Azad Pattan damsite.

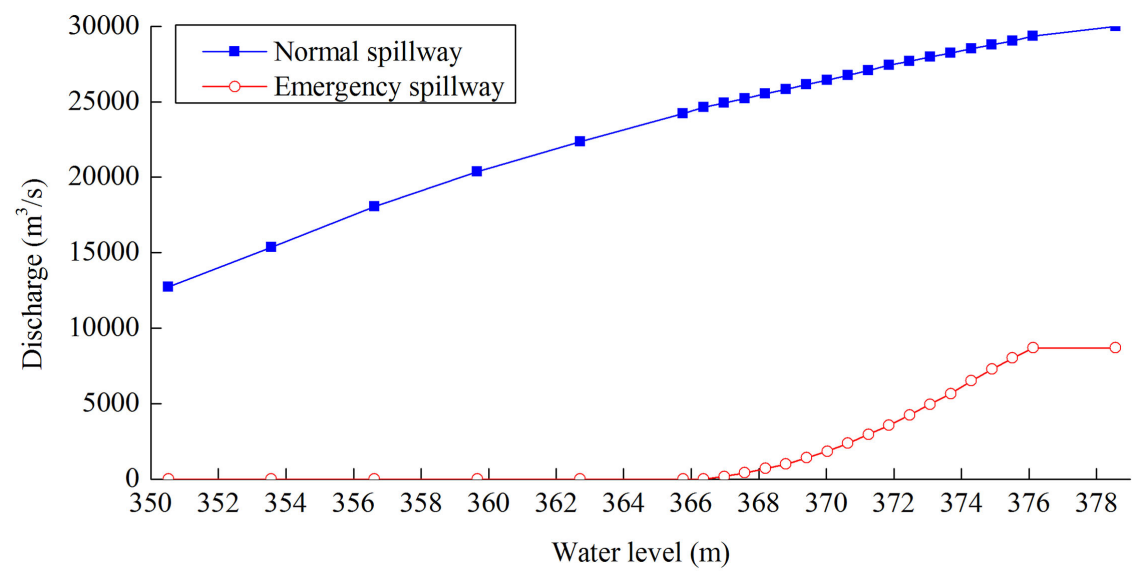

Figure 7. Discharge capacity curve of normal spillway and emergency spillway of Mangla reservoir.

3) Dam break mode and breach development process

Karot Dam is asphalt concrete core rock-fill dam. In accordance with related codes and regulations for dam-break flow [8] [9], its dam break mode and breach development process are set up as follows:

Dam break mode: gradual whole failure after crest overflow under the condition of probable maximum flood.

Dam break timing: under the condition of probable maximum flood, the dam starts to break when reservoir water level surpasses dam crest elevation, i.e. 469.5 m.

Dam breach expansion process: the type of dam breach gate can be approximated as trapezoid. Under the condition of probable maximum flood, the bottom elevation of dam breach will break uniformly over time from $469.5 \mathrm{~m}$ to 410 $\mathrm{m}$, and the breach width will linearly expand over time from $0 \mathrm{~m}$ to $180 \mathrm{~m}$, the left and right side slope of dam breach is taken as 1:1.5 (verticality: horizontality), the final form of dam breach is shown in Figure 8.

4) Time step and initial conditions

Time step: $1 \mathrm{~s}$. 


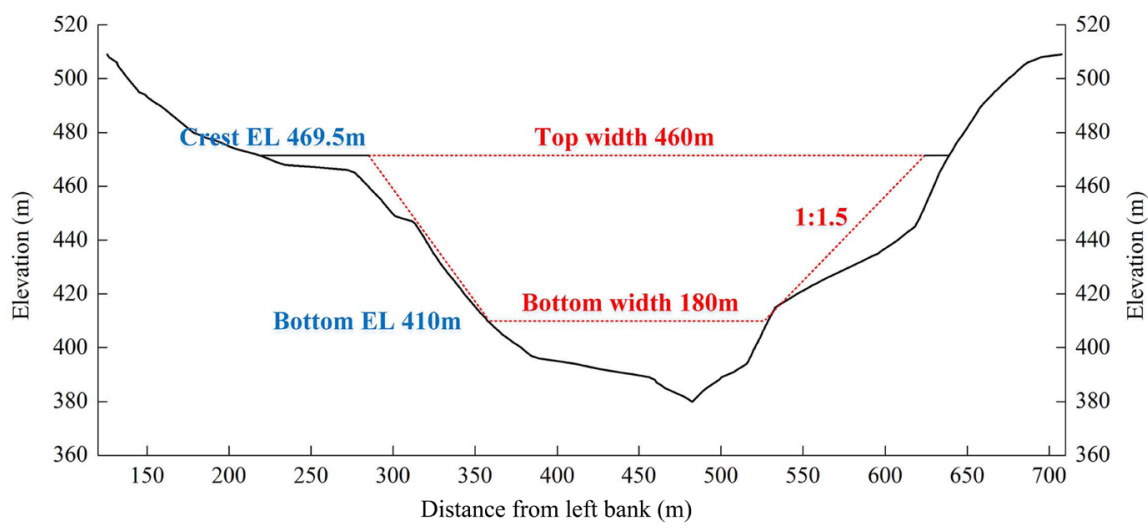

Figure 8. Schematic diagram of Karot Dam break breach under the condition of probable maximum flood.

Initial water level: Initial water level of Karot break model is considered as NPL $461 \mathrm{~m}$, initial water level between Karot damsite and Mangla damsite is considered as NPL $378.56 \mathrm{~m}$ of Mangla hydropower station; for the river reach with bed elevation higher than $378.56 \mathrm{~m}$, its initial water level is considered according to the initial water level of adjacent river sections and the slope of river.

\section{Results}

Karot Hydropower Station is a Class II large (2) hydro project; its water retaining structure is an asphalt concrete core rockfill dam. According to Karot dam break modelling results in "Feasibility Study of 720 MW Karot Hydropower Project", the full breach formation time is 2 hours. This report has used standard values of the breach parameters. No discussion is made to uncertainty of the parameters. The estimation of the breach parameters can have a significant effect on the final peak discharge at the dam site so an understating of the uncertainty is important. According to the dam break data of the same type dam, the dam break durations are generally longer than $5.5 \mathrm{~h}$. Therefore, the model should be rerun for at least one more breach time, to test the sensitivity to this parameter. Depending on the result of this sensitivity check, more robust conclusions could be made, or the model could be rerun for other values to gain a better understating of the likely impacts.

In this paper, $1 \mathrm{~h}, 2 \mathrm{~h}, 3 \mathrm{~h}, 4 \mathrm{~h}, 5 \mathrm{~h}, 6 \mathrm{~h}, 7 \mathrm{~h}, 8 \mathrm{~h}, 9 \mathrm{~h}, 10 \mathrm{~h}, 11 \mathrm{~h}, 12 \mathrm{~h}, 13 \mathrm{~h}, 14$ h, 15 h, 16 h, 17 h, 18 h, 19 h, 20 h, 21 h, 21 h, 23 h, 24 h of dam break duration schemes under the condition of probable maximum flood were set up to analysis the sensitivity of peak discharge, downstream highest flood water surface profile, flood peak appearance time and submerged real objects below KAROT dam to dam break duration.

\subsection{Sensitivity Analysis of Peak Discharge}

Under the condition of different dam break durations, damsite discharge process is as shown in Figure 9; damsite peak discharge is as shown in Figure 10. It can be seen that: after the dam break, the peak discharge at the Karot damsite is 


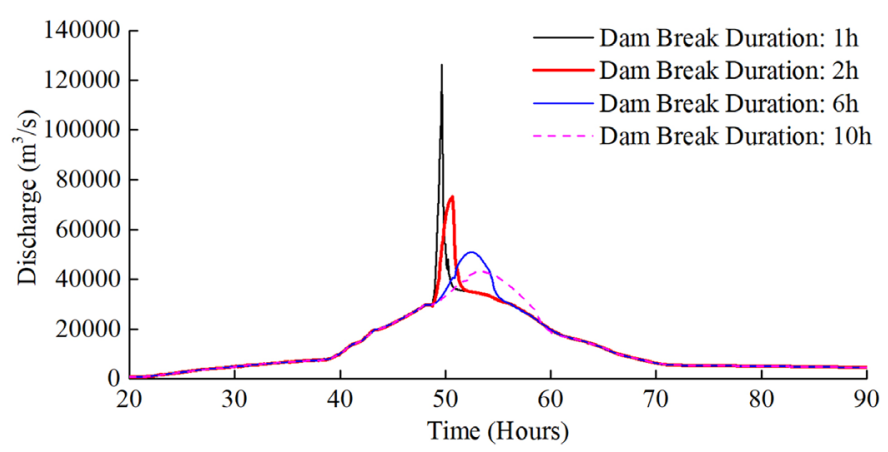

Figure 9. Damsite discharge processes under different dam break durations.

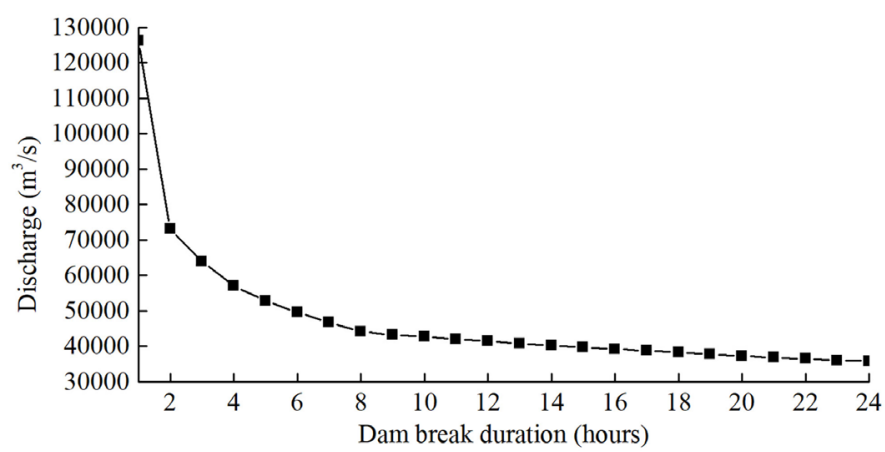

Figure 10. Damsite peak discharge under different dam break durations.

great, however, the duration of flood peak is short. When the dam break duration increases from $1 \mathrm{~h}$ to $24 \mathrm{~h}$, and after start of Karot dam break, the damsite peak discharge is decreased by $90,403 \mathrm{~m}^{3} / \mathrm{s}$ from $126,244 \mathrm{~m}^{3} / \mathrm{s}$ to $35,841 \mathrm{~m}^{3} / \mathrm{s}$. When the dam break duration is shorter than $2 \mathrm{~h}$, the damsite peak discharge is declined rapidly with the increase of breach failure time, and when the dam break duration is longer than $9 \mathrm{~h}$, the damsite peak discharge is increased insignificantly.

The peak discharge of dam break flood within the range of $40 \mathrm{~km}$ downstream of dam is attenuated quickly, as shown in Figure 11. When the dam break duration is $2 \mathrm{~h}$, it is decreased by $17,780 \mathrm{~m}^{3} / \mathrm{s}$ from $73,092 \mathrm{~m}^{3} / \mathrm{s}$ to $55,312 \mathrm{~m}^{3} / \mathrm{s}$, that is, $593 \mathrm{~m}^{3} / \mathrm{s}$ declined in $1 \mathrm{~km}$ on average. When the dam break duration is $9 \mathrm{~h}$, it is only decreased by $1932 \mathrm{~m}^{3} / \mathrm{s}$. After the attenuation, the flood discharge is still far greater than the worst natural flood discharge with 10,000 years recurrence $\left(32,300 \mathrm{~m}^{3} / \mathrm{s}\right)$. The area outside the range of $40 \mathrm{~km}$ downstream of the Karot dam is river network region and the Mangla reservoir area. It is influenced obviously by the pondage action of the Mangla reservoir and tributaries along the river, which makes the less attenuation of on-way peak discharge.

\subsection{Sensitivity Analysis of Downstream Highest Flood Water Surface Profile}

Under the condition of different dam break durations, the highest flood water surface profile from Karot damsite to Mangla damsite is as shown in Figure 12. 
It can be seen that: When the dam break duration increases from $1 \mathrm{~h}$ to $14 \mathrm{~h}$, the on-way highest water level from Karot damsite to Mangla damsite is lowered by $0.22-21.48 \mathrm{~m}$, and the lowering of water level is mainly located in the reaches from 1 to $40 \mathrm{~km}$ below Karot dam. When the dam break duration is shorter than $6 \mathrm{~h}$, the highest flood water surface profile is declined rapidly with the increase of breach failure time, and when the dam break duration is longer than $9 \mathrm{~h}$, the highest flood water surface profile is increased insignificantly.

\subsection{Sensitivity Analysis of Flood Peak Appearance Time}

When the dam break duration is $2 \mathrm{~h}$, the discharge process of on-way typical section at downstream of dam after the Karot dam break is as shown in Figure 13. It can be seen that: after the dam break, the flood peak transmits quickly. It takes $14 \mathrm{~min}, 57 \mathrm{~min}$ and $1 \mathrm{~h} 23 \mathrm{~min}$ respectively to transmit the flood peak to the location where is $20 \mathrm{~km}, 50 \mathrm{~km}$ and $73 \mathrm{~km}$ away downstream of dam. The average travel distance per minute is $0.5-1.8 \mathrm{~km}$.

\subsection{Sensitivity Analysis of Submerged Real Objects}

Under the condition of different dam break durations, the submerged real objects below Karot dam are as shown in Figure 14 and Table 1. It can be seen that: When the dam break duration is $2 \mathrm{~h}$, the submerged real objects are 2

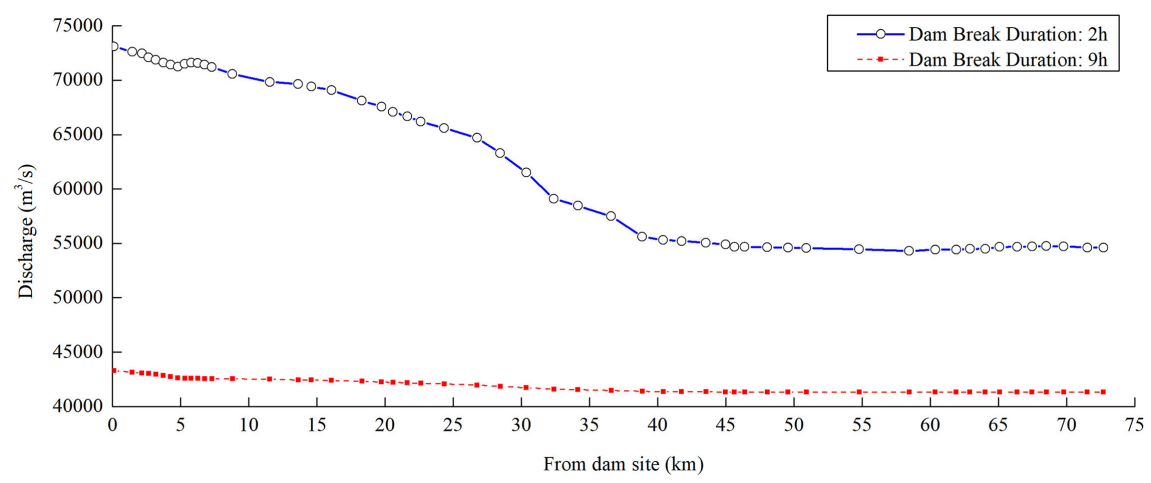

Figure 11. On-way peak discharge along downstream of dam after dam break.

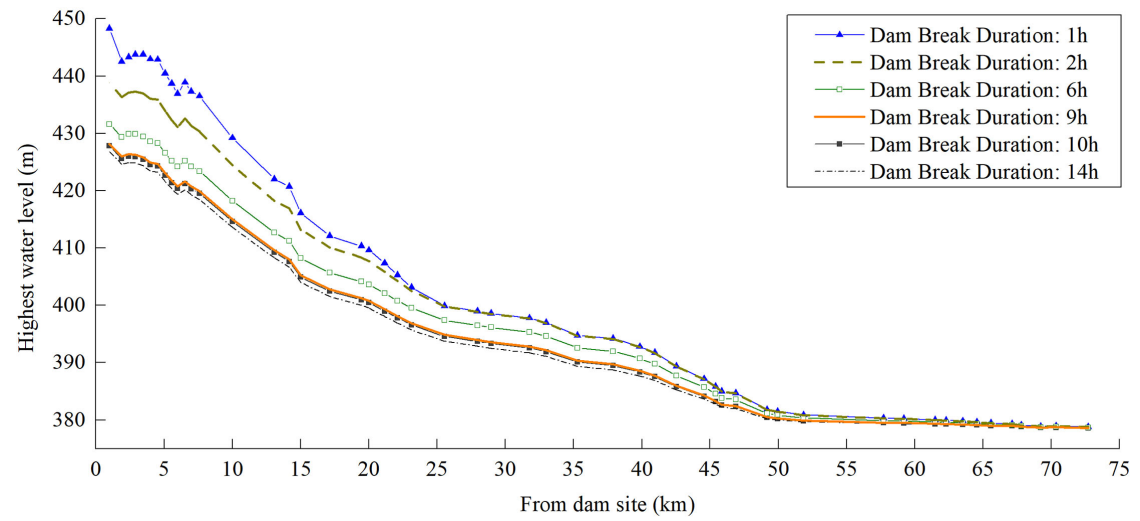

Figure 12. On-way highest water levels below dam under different dam break durations. 


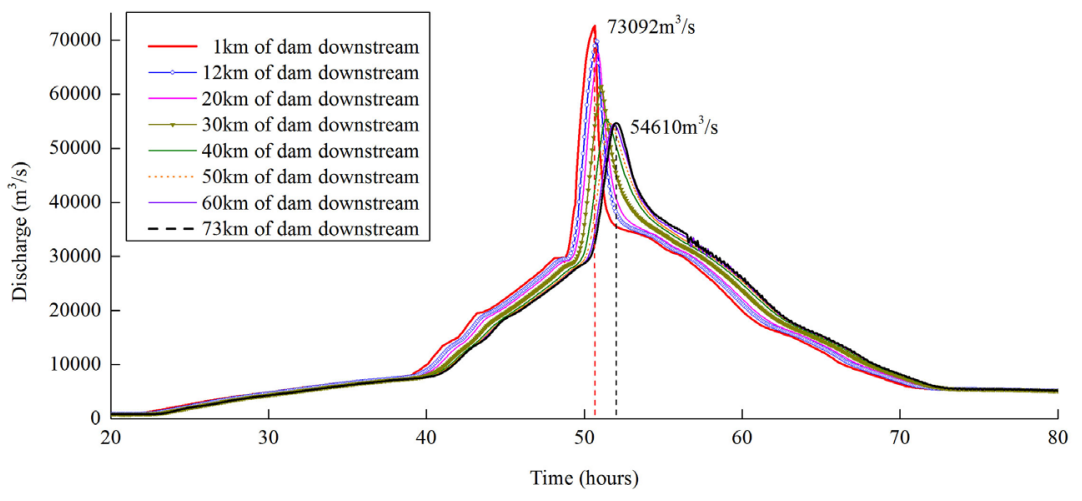

Figure 13. Discharge process of on-way typical section at downstream of dam after the dam break.

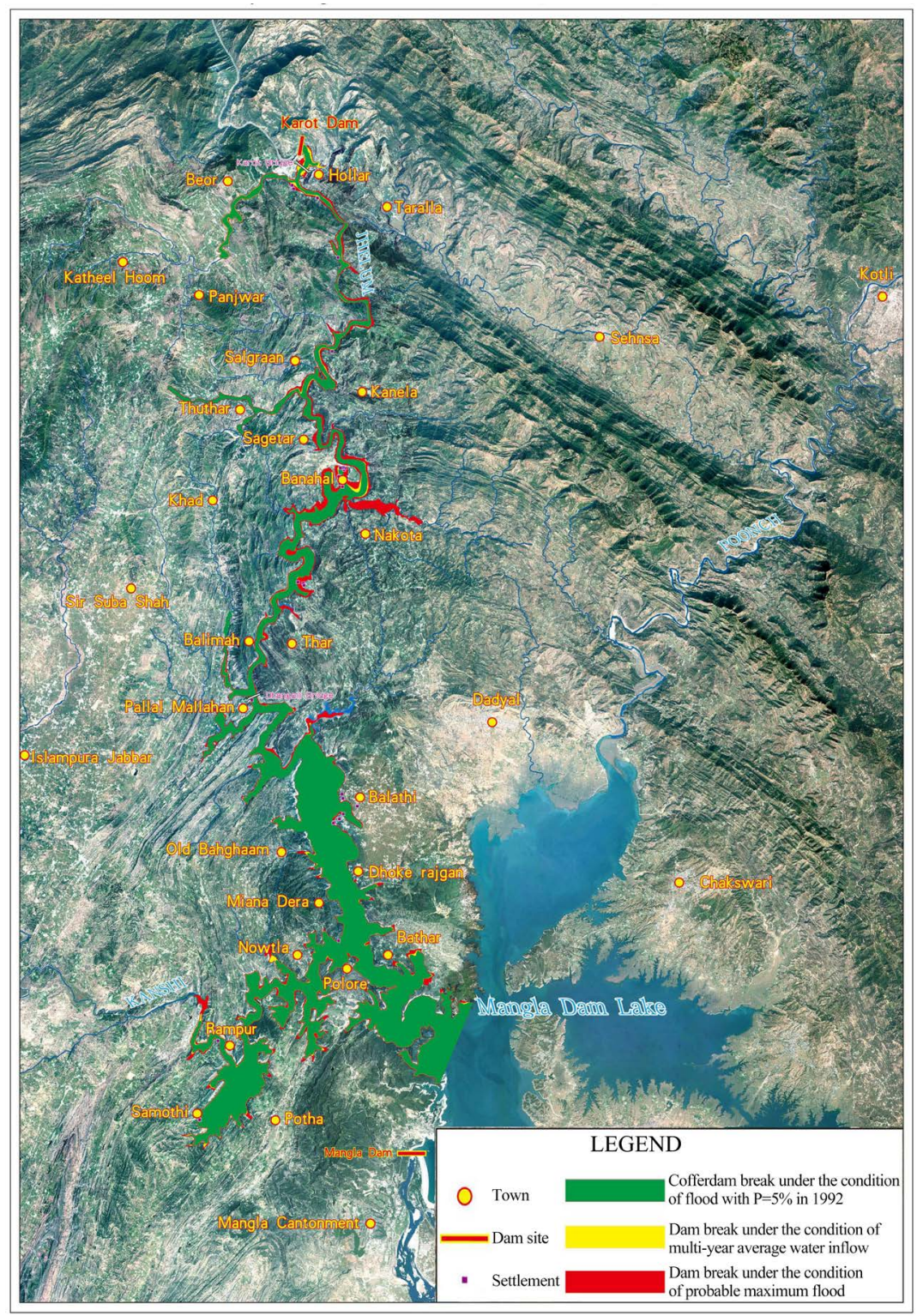

Figure 14. Flooding range map below the Karot hydropower station corresponding to the dam break duration of $2 \mathrm{~h}$. 
Table 1. Submerged depth comparison for the settlement places along bank and crossing bridges at the lower reach of dam under different dam break duration schemes.

\begin{tabular}{|c|c|c|c|c|}
\hline \multirow{2}{*}{ No. } & \multirow{2}{*}{$\begin{array}{l}\text { Mileage to the dam } \\
\qquad(\mathrm{km})\end{array}$} & \multicolumn{2}{|c|}{ Submerged depth (m) } & \multirow[t]{2}{*}{ Remarks } \\
\hline & & $2 \mathrm{~h}$ & $6 \mathrm{~h}$ & \\
\hline 1 & 1.0 & 10.8 & 3.6 & Karot Bridge \\
\hline 2 & 2.5 & 14.4 & 7.2 & House \\
\hline 3 & 2.6 & 22.0 & 14.7 & House \\
\hline 4 & 3.8 & 20.1 & 12.6 & House \\
\hline 5 & 7.6 & 14.7 & 7.7 & House \\
\hline 6 & 15.0 & -0.2 & -- & House \\
\hline 7 & 26.0 & 9.2 & 6.8 & Cottage \\
\hline 8 & 26.1 & 9.1 & 6.7 & House \\
\hline 9 & 26.1 & 7.3 & 5.0 & Cottage \\
\hline 10 & 26.2 & 10.2 & 7.9 & House \\
\hline 11 & 26.2 & 15.1 & 12.8 & Cottage \\
\hline 12 & 28.8 & 15.7 & 13.4 & Cottage \\
\hline 13 & 28.8 & 16.0 & 13.7 & Cottage \\
\hline 14 & 28.8 & 11.5 & 9.3 & Cottage \\
\hline 15 & 28.9 & 11.6 & 9.3 & House \\
\hline 16 & 28.9 & 15.1 & 12.8 & House \\
\hline 17 & 29.0 & 14.6 & 12.2 & Cottage \\
\hline 18 & 29.0 & 17.0 & 14.7 & House \\
\hline 19 & 37.9 & - - & -- & House \\
\hline 20 & 37.9 & 3.6 & 1.4 & House \\
\hline 21 & 37.9 & 7.2 & 5.1 & Dangali Bridge \\
\hline 22 & 45.9 & - - & -- & It is suspected to be deserted house \\
\hline 23 & 45.9 & - - & -- & Cottage \\
\hline 24 & 57.3 & - - & -- & House \\
\hline 25 & 57.5 & - - & -- & Cottage \\
\hline 26 & 57.7 & - - & -- & House \\
\hline 27 & 57.9 & - & -- & House \\
\hline 28 & 58.2 & -- & -- & House \\
\hline 29 & 58.5 & - & -- & House \\
\hline 30 & 58.7 & -- & -- & House \\
\hline 31 & 65.1 & 1.8 & 1.6 & House \\
\hline 32 & 78.6 & -- & -- & House \\
\hline 33 & 78.7 & -- & -- & Cottage \\
\hline
\end{tabular}


crossing bridge (Karot Bridge and Dangali Bridge) and 19 settlement places, which located in the range of $1-40 \mathrm{~km}$ away below Karot dam and at the Kanshi estuary. When the dam break duration increases from $2 \mathrm{~h}$ to $6 \mathrm{~h}$, only one settlement place located in $15.0 \mathrm{~km}$ below Karot dam can avoid being inundated. Therefore, the dam break duration is not sensitive for the submerged real objects below Karot dam.

\section{Conclusions}

According to the rock-fill dam break flood sensitivity check results, the conclusions can be drawn:

1) Peak discharge, downstream highest flood water surface profile and flood peak appearance time are sensitive for the breach failure time. With the increase of breach failure time, the damsite peak discharge and downstream highest flood water surface profile are declined little by little, but the decreasing amplitude is reduced gradually to stability, and the flood peak appearance time increases first and then decreases later. For Karot dam, $9 \mathrm{~h}$ is the critical value of dam break duration, so some measures of reducing break flood loss can be taken to extend the break duration. However, influenced by topography and distribution of settlements, the dam failure duration has little influence on the submerged real objects, so the super-standard flood countermeasures of ex-tending break duration are not very effective.

2) The occurrence of Karot Hydropower Station dam break will form tremendous dam break flood. On the grounds of sensitivity analysis results, the break duration is unlikely to last less than $2 \mathrm{~h}$. But from the worst disadvantage, Karot Dam would totally break in PMF inflow and $2 \mathrm{~h}$ break duration scheme, and dam site peak discharge reaches $73,092 \mathrm{~m}^{3} / \mathrm{s}$, more than dam site 10,000-year recurrence natural flood $\left(32,300 \mathrm{~m}^{3} / \mathrm{s}\right)$.

3) Karot Hydropower Station dam-break flood will cause severe flood disaster on dam area and the downstream area of the dam. After dam break, break flood would mainly progress in dam downstream channel and flow backward into interval tributaries; its inundation range is mainly in riparian zone on channel banks and low-lying housing estates and crossing bridges along the banks, submerged objects are mainly concentrated in right bank col 20 - $30 \mathrm{~km}$ downstream of dam and Kanshi estuary. Dam break will occur in PMF condition, settlements submerged number by dam break flood is around to 19, and Karot Bridge and Dangali Bridge would be submerged.

4) Relevant management and operation unit shall intensify flood control material preparation and flood early warning forecast. When it is forecasted that Karot damsite flood will exceed the spillway flood releasing capacity, the reservoir is pre-discharged to ensure dam safety; when it is forecasted that Karot damsite flood may possibly lead to dam break, we should immediately organize personnel for evacuation; as it takes a short time dam break flood spreading to downstream Mangla damsite, Mangla Hydropower Station has no time to con- 
duct pre-discharge upon Karot dam break; it is therefore suggested to strengthen flood early warning forecast and discharging flood in advance when it is forecast that upstream Azad Pattan Hydrological Station has occurred super-standard flood.

\section{Acknowledgements}

The authors gratefully acknowledge the support of the National Key Research and Development Program of China (Grant Nos. 2018YFC1508005).

\section{Conflicts of Interest}

The authors declare no conflicts of interest regarding the publication of this paper.

\section{References}

[1] Chen, S.S., Chen, Z.Y. and Zhong, Q.M. (2019) Progresses of Studies on Failure Mechanism and Numerical Dam Failure Model of Earth-Rockfill Dam and Landslide Dam. Water Resources and Hydropower Engineering, 50, 27-36.

[2] Chen, Z.Y., Chen, S.S., Wang, L. and Zhang, Q. (2019) Analysis of Earth-Rock Dam Break Flood: Theory and Calculation Program. Hydro Science and Cold Zone Engineering, 2, 12-19.

[3] Dam Safety Management Center of Ministry of Water Resources (2019) National Register of Dam Breaks. Dam Safety Management Center of Ministry of Water Resources, Beijing.

[4] DHI Water \& Environment (2004) MIKE 11-A Modelling System for Rivers and Channels. DHI Water \& Environment, Denmark.

[5] Du, X.H. (2019) Analysis and Research on the Safety Status of Dams in China. Water Power, 45, 64-69, 73.

[6] Jia, X.H. (2019) Sensitivity Analysis of Seismic Dynamic Response about Earth-Rock Dams of the Plain Reservoir. Pearl River, 40, 18-23, 42.

[7] Li, C.W., Ma, Q., Jiang, L., et al. (2019) Analysis on Karot Dam (Cofferdam) Break Flood in Pakistan. Changjiang Survey, Planning, Design and Research Co., Ltd, Wuhan.

[8] Liu, H.L. and Li, H.Q. (2019) Simulation of Dam-Break Flow Based on Smoothed Particle Hydrodynamics. Yangtze River, 50, 150-154, 159.

[9] Mei, J.S., Zhong, Z.Y., An, Y.G., et al. (2015) Water Conservancy Industry Standard of the People's Republic of China (SL 104-2015): Regulations for Water Conservancy Computation of Water Projects. Ministry of Water Resources, People's Republic of China, Beijing.

[10] Ministry of Water Resources, National Bureau of Statistics, People's Republic of China (2013) Bulletin of First National Census for Water. China Water \& Power Press, Beijing.

[11] Ministry of Water Resources, People's Republic of China (2018) 2017 Statistic Bulletin on China Water Activities. China Water \& Power Press, Beijing.

[12] Pratiwi, V., Kusuma, M.S.B., Kardhana, D. and Farid, M. (2021) Comparison of Physical and Numerical Model on Dam Break Flood Wave Propagation in Horizontal Channel. IOP Conference Series: Materials Science and Engineering, 1158, 
Article ID: 012015. https://doi.org/10.1088/1757-899X/1158/1/012015

[13] Oguzhan, S. and Aksoy, A.O. (2020) Experimental Investigation of the Effect of Vegetation on Dam Break Flood Waves. Journal of Hydrology and Hydromechanics, 68, 231-234. https://doi.org/10.2478/johh-2020-0026

[14] Xu, Z.M., Wang, Y.Z. and Ning, L. (2008) Main Understanding of Tangjiashan Dammed Lake Break Flood Calculation. Yangtze River, 39, 86-88, 104.

[15] Zhang, X.F., Jiang, H.P., Huang, G.B., et al. (2006) Electrical Industry Standard of the People's Republic of China (DL/T 5360-2006): Code for Simulation of Dam-Break Flow for Hydropower and Hydraulic Engineering. National Development and Reform Commission, People's Republic of China, Beijing.

[16] Zhou, C., Xu, W.L., Huang, M.H., et al. (2010) Water Conservancy Industry Standard of the People's Republic of China (SL 164-2010): Regulations for Simulation of Dam-Break Flow. Ministry of Water Resources, People's Republic of China, Beijing. 